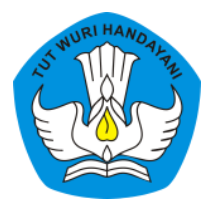

Page: 19-38

\title{
Pengembangan Media X-Box untuk Meningkatkan Pemahaman Siswa Sekolah Dasar tentang Perkalian
}

\author{
Kristiningrum \\ Sekolah Dasar Negeri Karang Satria 04 Tambun Utara \\ Contributor Email: kristinningrum15@gmail.com
}

Published: Mar 30, 2020

Article Url: http:/ / ojsdikdas.kemdikbud.go.id/index.php/didaktika/article/view/123

\begin{abstract}
This learning innovation work was created based on the finding that students in primary schools still have difficulty in multiplication operations of up to four digits. There is no use of innovative media in learning that can be used effectively for multiplication learning. The making and use of X-boX media is to make it easy for students to understand and be proficient in performing multiplication calculation operations. The method used in this study is the design and development (DED) by testing using tests given to students and design validation by experts. Obtained results of media validation by $94 \%$ and material validation by $82 \%$. Experts claim that this innovation work is in the good category and is suitable for use in learning about multiplication. Based on the results of the reflection made, the X-boX media was considered effective in increasing student understanding. Evidenced by the average value of student learning outcomes that are above the KKM value after testing.
\end{abstract}

Keywords: X-boX Media, Multiplication Calculations, Mathematics 


\begin{abstract}
Abstrak
Karya inovasi pembelajaran ini diciptakan atas dasar temuan bahwa siswa di sekolah dasar masih kesulitan dalam melakukan operasi hitung perkalian sampai empat digit. Belum ada penggunaan media inovasi dalam pembelajaran yang dapat digunakan secara efektif untuk pembelajaran perkalian. Pembuatan dan penggunaan media X-boX yakni untuk memberikan kemudahan bagi siswa untuk memahami dan mahir dalam melakukan operasi hitung perkalian. Metode yang digunakan pada penelitian ini adalah perancangan dan pengembangan (DED) dengan pengujian menggunakan tes yang diberikan pada siswa serta validasi perancangan oleh para ahli. Diperoleh hasil validasi media sebesar $94 \%$ dan validasi materi sebesar $82 \%$. Para ahli menyatakan bahwa karya inovasi ini masuk dalam kategori baik dan layak digunakan dalam pembelajaran tentang perkalian. Berdasarkan hasil refleksi yang dilakukan, media XboX dinilai efektif untuk meningkatkan pemahaman siswa. Terbukti dengan nilai ratarata hasil belajar siswa yang berada di atas nilai KKM setelah dilakukan tes pengujian.
\end{abstract}

Kata Kunci: Media X-boX, Operasi Hitung Perkalian, Matematika

\title{
A. Pendahuluan
}

Saat ini guru sebagai pemeran utama dalam dunia pendidikan seharusnya dapat menerapkan pembelajaran abad 21 pada kegiatan pembelajaran. Hal ini perlu dilakukan untuk menciptakan pembelajaran yang komunikatif, kreatif, kolaboratif dan berpikir kritis sehingga siswa mampu mengintegrasikan pengetahuan, keterampilan dan kreatifitas disaat yang bersamaan. Kegiatan belajar dengan menerapkan pembelajaran abad 21 ini dapat menjawab tantangan revolusi industri 4.0 terutama yang terkait dengan literasi teknologi dalam pemanfaatan media, teknologi, informasi dan komunikasi. Pembelajaran seperti ini sesuai dengan tujuan pendidikan nasional abad 21 yaitu menciptakan bangsa Indonesia yang sejahtera dan bahagia yang setara kedudukannya dengan bangsa lain di dunia global, melalui pembentukan generasi Indonesia yang berkualitas pada pribadi yang memiliki kemauan, kemampuan dan kemandirian dalam mewujudkan cita-cita bangsa.

Pendidikan matematika pada sekolah dasar seharusnya dapat memberikan dasar yang kuat dalam penalaran siswa sehingga kesulitan dalam menyelesaikan berbagai permasalahan yang berkaitan dengan 


\section{Kristiningrum}

matematika dapat diatasi dengan baik oleh siswa. Selain itu diharapkan kemampuan siswa dalam berpikir secara logis, realistis dan kritis dapat berkembang dengan baik pada pembelajaran matematika disekolah dasar. Hal tersebut dapat tercapai apabila siswa menyukai pembelajaran matematika sehingga dapat mempengaruhi prestasi siswa kearah yang lebih baik.

Namun pada kenyataannya, matematika bagi sebagian besar siswa sekolah dasar dianggap sebagai pelajaran yang sulit terutama pada materi perkalian sehingga kebanyakan siswa tidak menyukai pelajaran matematika. Hal tersebut disebabkan karena kegiatan pembelajaran matematika disajikan menggunakan metode yang hanya bersifat "one way" dimana hanya guru yang aktif sehingga tidak ada umpan balik atau feed back dari siswa. Selain itu tidak tercipta pembelajaran yang menyenangkan pada pembelajaran matematika sehingga sebagian besar siswa sulit untuk memahami materi matematika yang disampaikan guru.

Perkalian merupakan salah satu materi matematika yang paling dasar dalam berhitung yang nantinya akan digunakan dalam beberapa konsep materi matematika yang lainnya, diantaranya dalam menentukan debit, menghitung luas bangun datar, menghitung voume bangun ruang, mengolah data dan masih banyak lagi, bahkan dalam kehidupan seharihari pun tidak terlepas dari penerapan perkalian. Oleh sebab itu, perkalian menjadi satu hal penting yang harus dipahami dan dikuasai siswa.

Dari pengamatan di kelas VI SDN Karang Satria 04 banyak didapati siswa yang masih sangat kurang dalam penguasaan perkalian. Dari 39 siswa, 48\% siswa masih kurang menguasai perkalian penyebabnya karena teknik yang digunakan masih menggunakan teknik lama yaitu teknik bersusun. Dimana pada teknik ini menggunakan metode menyimpan angka yang biasanya siswa sering lupa untuk menjumlah angka yang disimpan tersebut sehingga menyebabkan hasil yang didapat pada perkalian tidak tepat. Selain itu pembelajaran lebih kepada teacher centre (terpusat pada guru) serta tidak adanya media pembelajaran yang digunakan dalam kegiatan belajar. 
Berdasarkan temuan tersebut, agar pemahaman siswa pada perkalian menjadi lebih baik harus digunakan metode, teknik dan media yang tepat agar pembelajaran menjadi menarik sehingga pemahaman dan kemampuan siswa dalam perkalian menjadi meningkat. Untuk itu dan dalam rangka menjawab tantangan revolusi industri 4.0 yang identik dengan komputer super penulis mencoba mengembangkan media X-boX. Media X-boX memudahkan siswa melakukan perhitungan perkalian tanpa harus "mencederai" proses pembelajaran dan pada akhirnya dapat meningkatkan hasil belajar siswa. Rumusan masalah dalam penelitian ini adalah: bagaimana rancangan media $\mathrm{X}$-boX dan bagaimana efektifitas penggunaan media $\mathrm{X}$-boX dalam meningkatkan pemahaman perkalian pada siswa. Dari rumusan masalah tersebut, tujuan pembelajaran yang diperoleh adalah Untuk mengetahui rancangan media X-boX dan mengetahui efektifitas penggunaan media X-boX dalam meningkat pemahaman siswa pada perkalian.

Hasil penelitian diharapkan dapat memberikan manfaat: meningkatkan pemahaman siswa pada perkalian menggunakan media XboX, memberikan pengalaman belajar yang lebih menarik, menyenangkan mengasikkan dengan melakukan pembelajaran menggunakan aplikasi pada gawai, mengembangkan karakter peserta didik seperti kerjasama, keberanian, percaya diri dan tanggung jawab dalam kegiatan belajar mengajara, serta memotivasi siswa untuk meningkatkan hasil belajar pada mata pelajaran matematika.

Pengembangan dalam (KBBI, 2019) artinya adalah proses. Menurut Seels dan Richey (Sumarno, 2012) pengembangan berarti penjabaran spesifikasi suatu desain dalam bentuk benda atau konkret. Sedangkan menurut Iskandar Wiryokusumo (Wiryokusumo, 2011), pengembangan adalah usaha yang dilakukan secara sadar dan terencana dengan baik dibidang pendidikan baik formal atau informal sebagai upaya melakukan bimbingan dan pengembangan terhadap pengetahuan dan keterampilan sesuai dengan kompetensi, keinginan dan bakatnya untuk dapat mengembangkan diri dan meningkatkan kemampuan diri 


\section{Kristiningrum}

secara maksimal serta menjadi pribadi yang mandiri. Sehingga dapat disimpulkan bahwa pengembangan merupakan proses meningkatkan mutu produk untuk lebih baik dan lebih banyak memiliki nilai manfaat yang dilakukan secara sadar dan terencana dengan baik.

Sedangkan arti media menurut Gagne (Gagne, 2006) adalah semua komponen yang berada disekitar siswa yang dapat memotivasi kompetensi siswa dalam belajar. Leslie J. Briggs (Briggs, 1981), berpendapat bahwa media adalah benda yang dapat di manfaatkan sebagai sarana untuk mentransfer ilmu pengetahuan, bisa dalam bentuk gambar, grafik, buku, video, kaset, televisi, video kamera, alat perekam suara dan komputer. Sehingga dapat dikatakan bahwa media adalah benda yang gunakan untuk mentransfer ilmu pengetahuan yang dapat memotivasi siswa untuk belajar.

Berdasarkan pendapat para ahli diatas dapat disimpulkan bahwa pengembangan media merupakan proses peningkatan kualitas dan penambahan nilai manfaat suatu benda yang digunakan untuk menyampaikan ilmu pengetahuan untuk merangsang keinginan dan kemampuan siswa dalam kegiatan pembelajaran.

Pada bidang pendidikan, teknologi komunikasi dan informasi ini sangat berkembang pesat penggunaannya. Sebagian besar guru telah memanfaatkan TIK ini untuk dapat menyampaikan materi pembelajaran kepada siswanya. Bahkan TIK ini untuk sebagian guru telah menjadi kebutuhan baik dalam mempersiapkan administrasi guru maupun sebagai media pembelajaran. Selain TIK penggunaan gawai juga saat ini banyak dimanfaatkan para guru untuk menyampaikan pesan dalam pembelajaran. Penggunaan gawai sebagai media pembelajaran ini sering dimanfaatkan sebagi media evaluasi dalam bentuk kuis-kuis atau sebagai media penyampai materi secara online maupun offline.

Pembelajaran matematika tentang perkalian pada sekolah dasar pun dapat memanfaatkan gawai sebagai media pembelajran yang efektif. Media pembelajaran menggunakan kotak perkalian berbasis android ditampilkan pada gawai yang proses pembuatan media tersebut 
memanfaatkan perangkat lunak pada TIK dimana outputnya berupa aplikasi X-boX yang dapat dipasang pada android.

Dalam sindonews (Keswara, 2016), DR. Wahidin dalam ensiklopedia yang disusunnya, metode perkalian dengan kotak perkalian pernah digunakan oleh ilmuan india sebelum abad 12 akan tetapi nama ilmuan yang menemukan dan menggunakannya tidak diketahui. Cara yang digunakan masih secara manual atau hanya menggunakan kertas dan pensil/pulpen. Penulis melakukan inovasi kotak perkalian manual tersebut dibuat dalam bentuk aplikasi android dengan tujuan agar siswa lebih meyukai karena tampilannya yang lebih menarik dan siswa lebih memahami dan mahir dalam melakukan perkalian antara beberapa digit angka dimana hasil perhitungannya dapat divalidasi. Setelah siswa menguasai perkalian menggunakan kotak perkalian pada media X-boX maka siswa pun akan mahir melakukan perkalian dengan menggunakan kotak perkalian secara manual.

Media X-boX ini terdiri dari kotak-kotak dan dilengkapi dengan sistem validasi untuk mengolah angka yang dibuat pada perangkat android, yang betujuan untuk memudahkan siswa dalam melakukan opeasi hitung perkalian serta menghilangkan anggapan siswa tentang "matematika pelajaran yang sulit" menjadi "matematika pelajaran yang mudah". Kotak perkalian tersebut di tampilkan pada gawai dalam bentuk aplikasi edukatif. Inovasi pada gawai ini dimaksudkan selain untuk mendapatkan penampilan yang lebih menarik agar siswa lebih tertarik, dapat menciptakan pembelajaran lebih menyenangkan yang dapat menghilangkan kebosanan dalam pembelajaran matematika sehingga mengubah anggapan matematika pelajaran yang menyebalkan menjadi pelajaran yang menyenangkan. Aplikasi ini juga cukup pratis karena dapat dibawa kemana pun, dimanfaatkan dimanapun, dan oleh siapapun.

Pada pelajaran matematika kita sangat mengenal dengan operasi hitung, dimana operasi hitung itu terdiri dari penjumlahan, pengurangan, perkalian dan pembagian. Operasi hitung ini pun tidak lepas penerapannya dalam kehidupan sehari-hari. Operasi hitung tersebut 
menjadi pondasi dasar pada pelajaran matematika, karena operasi hitung ini akan terus digunakan pada materi-metri metematika yang lainnya.

Perkalian merupakan salah satu operasi hitung yang selalu digunakan dalam pembelajaran matematika setelah penjumlahan dan pengurangan. Oleh karena itu, siswa seharusnya dapat menguasai perkalian baik perkalian dasar maupun perkalian antara beberapa angka. Perkalian itu sendiri menurut Steve Slavin (Steve, 2005) adalah kecepatan dalam melakukan penambahan beberapa angka. Yasin Matika dan Abraham dalam Linda Nurmasari (Nurmasari, 2010), berpendapat bahwa perkalian adalah melakukan operasi penjumlahan pada angka-angka yang sama atau penjumlahan yang berulang. Misalnya, pada penjumlahan $6 \times 3$ dapat diartikan $3+3+3+3+3+3=18$, sedangkan $3 \times$ 6 dapat diartikan $6+6+6=18$. Secara konsep $6 \times 3$ tidak sama dengan $3 \times$ 6 , akan tetapi secara hasil $6 \times 3=3 \times 6$, oleh karena itu dalam perkalian bisa dilakukan sifat pertukaran atau komutatif.

Dari pemaparan diatas dapat disimpulkan bahwa secara konseptual perkalian bukan perkalian berulang, tetapi secara hasil yang didapat perkalian dapat dikatakan penjumlah berulang dan perkalian dapat memenuhi sifat pertukaran (komutatif). Selain itu dalam perkalian terdapat sifat khusus dan setiap siswa harus memahami sifat dan ciri khusus dari perkalian agar siswa mudah dalam melakukan operasi hitung perkalian. Berikut ini beberapa sifat dari perkalian:

1. Perkalian yang hasilnya 0 (nol) adalah angka yang dikalian dengan angka 0 (nol), contohnya : $6 \times 0=0 \quad 0 \times 9=0 \quad 4 \times 0=0$

2. Perkalian angka 1 (satu) dengan angka berapapun maka akan menghasilkan angka tersebut bukan angka 1 (satu), contoh : $5 \times 1=5$ $1 \times 7=7 \quad 3 \times 1=3$

3. Perkalian suatu angka dengan angka 10 (sepuluh), 100 (seratus), 1000 (seribu) hasilnya adalah angka tersebut dan diberi angka 0 (nol) sesuai dengan pengalinya. Misalnya, bila di kali 10 (sepuluh) diberi 1 angka 0 (nol) di belakangnya, bila dikali 100 (seratus) diberi 2 angka 0 (nol) di 
belakangnya, bila dikali 1000 (seribu) diberi 3 angka 0 (nol) dibelakangnya. Contohnya: $2 \times 10=20,100 \times 8=800,3 \times 1000=3000$

4. Perkalian memenuhi sifat pertukaran (komutatif).

Contohnya : $4 \times 5=5 \times 4=20 \quad 6 \times 2=2 \times 6=12$.

\section{B. Metode}

Metode yang digunakan dalam penelitian ini adalah perancangan dan pengembangan (design \& development) dimana bentuk desain penelitian adalah kualitatif, dengan teknik pengumpulan data menggunakan tes dan non tes, validasi materi dan validasi media oleh ahli media, analisis data menggunakan deskriptif kuantitatif dengan prosentase. Objek dari penelitian ini adalah siswa kelas VI SDN Karang Satria 04 Kab. Bekasi.

\section{Hasil dan Pembahasan}

Dalam pembuatan media $X-b o X$ pertama kali yang harus dilakukan adalah dengan membuat rancangan layout untuk menentukan tampilan dan fungsi yang akan dipasang pada karya inovasi. Tahap perancangan ini terdiri dari rancangan flowchart, rancangan storyboard, rancangan interface atau tampilan dan rancangan penulisan kode/syntax untuk dapat menjalankan aplikasi, yang terdiri dari:

\section{Membuat rancangan Flowcart}

Pada flowchart ditunjukkan alur penggunaan media X-boX, ketika mulai membuka aplikasi muncul splash screen atau tampilan pembuka sekitar tiga sampai lima detik lalu akan muncul menu screen atau tampilan menu yang berisi pilihan untuk kemenu berikutnya diantaranya menu petunjuk penggunaan, menu perkalian dua angka dengan dua angka, menu perkalian dua angka dengan tiga angka, menu perkalian tiga angka dengan tiga angka dan menu perkalian tiga angka dengan empat angka.

a. Membuat rancangan Storyboard

1) Splash Screen atau Tampilan Pembuka 


\section{Kristiningrum}

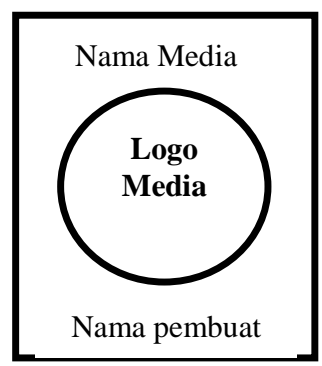

Pada splash screen ini akan tampil logo dan nama media inovasi serta nama pembuat media tersebut. Splash screen ini akan tambil selam tiga sampai lima detik dan kemudian akan muncul menu screen atau tampilan menu

Gambar 1 Storyboard Tampilan Pembuka

2) Menu Screen atau Tampilan Menu

Nama Media

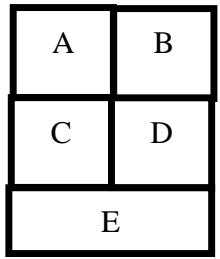

Nama pembuat

Gambar 2 Storyboard Tampilan Menu
Pada menu screen atau tampilan menu terdapat lima kotak yang dapat menampilkan screen berikutnya bila pengguna memilih salah satunya dengan mengkliknya.

- Kotak A lanjut ke screen perkalian dua angka dengan dua angka.

- Kotak B lanjut ke screen perkalian dua angka dengan tiga angka.

- Kotak C lanjut ke screen perkalian tiga angka dengan tiga angka

- Kotak D lanjut ke screen perkalian tiga angka dengan empat angka

- Kotak E lanjut ke screen yang berisi video cara penggunaan media tersebut.

b. Membuat rancangan Interface

1) Splash Screen atau Tampilan pembuka

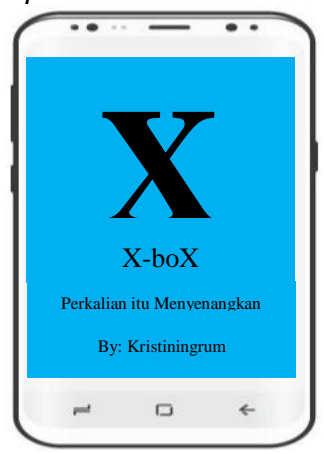

Splash screen akan muncul saat aplikasi pertama kali dibuka. Pada splash screen akan muncul symbol dari perkalian yaitu $X$ besar dan nama aplikasinya $X-b o X$. Splash screen akan muncul selama tiga samapai lima detik dan setelah itu secara otomatis akan masuk pada tampilan berikutnya, yaitu tampilan menu

Gambar 3 Interface Tampilan Pembuka 
2) Menu Screen atau tampilan menu

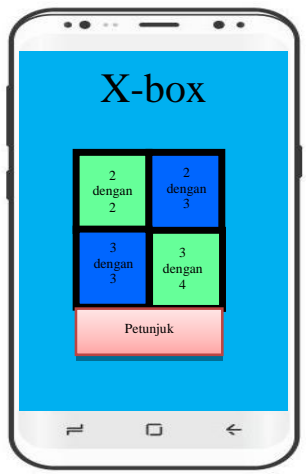

Pada Menu screen atau tampilan menu, terdapat lima buah kotak. Kotak tersebut terdiri dari kotak petunjuk, dan kotak perkalian mulai dari perkalian dua angka dengan dua angka sampai perkalian tiga angka dengan tiga angka. Bila pengguna mengklik salah satu kotak maka akan terhubung dengan screen atau tampilan yang diinginkan.

Gambar 4 Interface Tampilan Menu

3) Tampilan Petunjuk

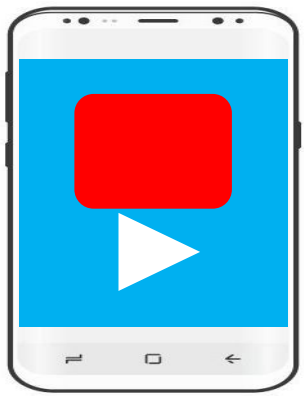

Ketika pengguna mengklik kotak petunjuk pada tampilan menu, maka secara otomatis akan muncul screen yang berisi video tutorial aplikasi $X$-boX. Video ini bertujuan agar pengguna dapat lebih memahami cara melakukan perhitungan perkalian menggunakan aplikasi $X-b o X$.

\section{Gambar 5 Interface Tampilan Petunjuk}

4) Screen Perkalian 2 angka dengan 2 angka

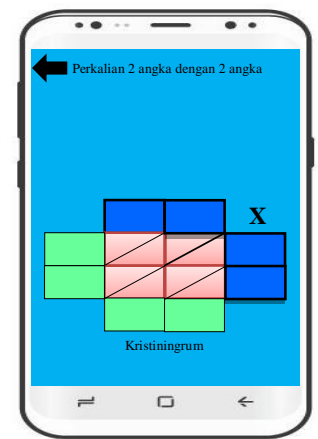

Pada screen ini ditampilkan kotak-kotak dengan warna yang berbeda. Untuk kotak berwarna biru diisi dengan angka perkalian 2 angka dengan 2 angka. Kotak warna merah diisikan dengan hasil perkalian dari kotak berwarna biru. Pada kotak hijau diisi oleh hasil dari penjumlahan angka pada kotak merah secara diagonal.

Gambar 6 Screen Perkalian 2 Angka dengan 2 Angka 


\section{Kristiningrum}

5) Screen Perkalian 2 angka dengan 3 angka

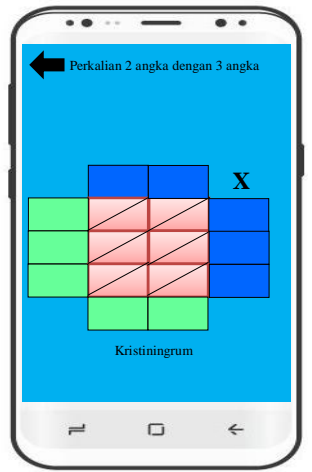

Pada screen ini sama dengan screen sebelum, akan ditampilkan kotak-kotak dengan warna yang berbeda. Untuk kotak berwarna biru diisi dengan angka perkalian 2 angka dengan 3 angka. Kotak warna merah diisikan dengan hasil perkalian dari kotak berwarna biru. Pada kotak hijau diisi oleh hasil dari penjumlahan angka pada kotak merah secara diagonal.

Gambar 7 Screen Perkalian 2 Angka dengan 3 Angka

6) Screen Perkalian 3 angka dengan 3 angka

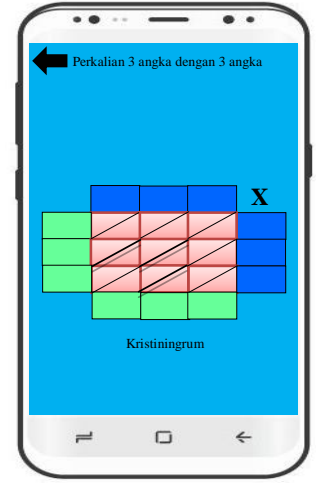

Pada screen ini sama dengan screen sebelum, akan ditampilkan kotak-kotak dengan warna yang berbeda. Untuk kotak berwarna biru diisi dengan angka perkalian 3 angka dengan 3 angka. Kotak warna merah diisikan dengan hasil perkalian dari kotak berwarna biru. Pada kotak hijau diisi oleh hasil dari penjumlahan angka pada kotak merah secara diagonal.

Gambar 8 Screen Perkalian 3 Angka dengan 3 Angka

7) Screen Perkalian 3 angka dengan 4 angka

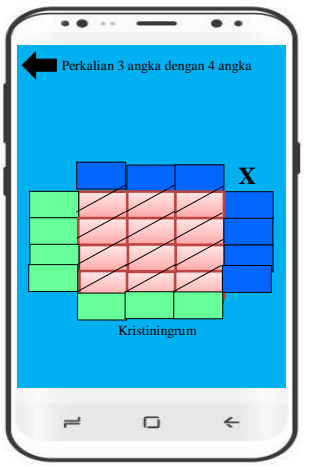

Pada screen ini sama dengan screen sebelum, akan ditampilkan kotak-kotak dengan warna yang berbeda. Untuk kotak berwarna biru diisi dengan angka perkalian 3 angka dengan 4 angka. Kotak warna merah diisikan dengan hasil perkalian dari kotak berwarna biru. Pada kotak hijau diisi oleh hasil dari penjumlahan angka pada kotak merah secara diagonal.

Gambar 9 Screen Perkalian 3 Angka dengan 4 Angka 
c. Pembuatan bahasa Pemrograman

1) Pembuatan Menu Utama

Pembuatan tampilan menu utama menggunakan xml dengan nama file activity_menu.xml. Tombol yang ada di menu utama di susun menggunakan table layout dan terdiri dari 3 baris dan 2 kolom. Kemudian untuk event click pada handle oleh kelas Menu Activity.kt. Di kelas tersebut tiap-tiap tombol di beri event click (*baris 20 - 24) dan jika nanti pengguna menekan tombol tersebut dibawa ke halaman lain sesuai tombol yang di klik.

2) Pembuatan halaman perkalian

Pembuatan tampilan halaman perkalian menggunakan $x \mathrm{ml}$ dengan nama file activity_x22 (*22 di sesuaikan dengan jumlah digit perkalian, misal untuk perkalian 2 digit $\times 2$ digit nama filenya activity_x22.xml, untuk perkalian 2 digit $\mathrm{x} 3$ digit nama file-nya activity_x23.xml).

Pada tabel perkaliannya disusun menggunakan table layout dan didalam tabel tersebut berisi widget edittext. Khusus untuk bagian tengah (bagian hasil angka perkalian) tiap kolom berisi 2 widget edittext yang di pisahkan garis diagonal.

Pada tombol periksa penanganan event click dilakukan pada file $x 22$ Activity.kt (sama seperti layout, 22 menunjukan jumlah digit angka perkalian) (*event klik ada di baris 24 untuk kelas $x 22$ Activity.kt).

Ketika tombol periksa diklik, proses pertama yang dilakukan adalah validasi untuk memastikan kolom yang berisi angka yang akan dikalikan (kolom warna biru) terisi semua, jika tidak akan ada pesan error dengan memanggil fungsi checkNulls (*baris 11 - 17) yang ada di kelas CommonUtil.kt ( ${ }^{*}$ difolder util). cara kerjanya yaitu mengirim widget edittext (yg ada kolom biru) dalam bentuk array dan kemudian akan diperiksa satu persatu oleh fungsi tersebut. Apabila terisi semua maka nilai kembaliannya true dan dilanjutkan ke proses selanjutnya, dan bila nilai kembaliannya false proses akan berhenti dan tampilan pesan error 


\section{Kristiningrum}

dikolom biru yg belum terisi. Kemudian setelah validasi yang dilakukan selanjutnya ada mengecek kolom merah yang berisi hasil perkalian kolom biru dengan memanggil fungsi checkRows (*baris 2229) yang ada dikelas CommonUtil.kt. cara kerjanya yaitu dengan mengalikan kolom biru sesuai urutan kemudian dibandingkan dengan isian pengguna, jika salah maka akan tampil pesan kesalahan tetapi walaupun ada pesan kesalahan proses tetap dapat dilanjutkan.

Proses selanjutnya yaitu mengecek hasil penjumlahan kolom merah secara diagonal dan membandingkan hasilnya dikolom hijau dengan memanggil fungsi diagonal Check ("baris ke 56- 72) di kelas CommonUtil.kt. bila salah akan ada pesan kesalahan di kolom tersebut.

Proses diatas berlaku disemua halaman perkalian. Fungsi yang dipanggil pun sama hanya berbeda pada parameter yang dikirim dan banyaknya jumlah pemanggilan fungsi-fungsi tersebut.

3) Pembuatan halaman pengenalan (introduction)

Untuk tampilan dibuat di-file activity_introduction.xml di mana hanya berisi widget videoView. Sedangkan untuk pemutaran video ditangani dikelas IntroductionActivity.kt. semua event yang ada di halaman ini sudah ditangani dikelas yang disediakan oleh android studio yaitu mediaController dan videoView (*baris ke 19 - 25).

Inovasi Pembelajaran X-boX ini telah diterapkan dalam kegiatan pembelajaran matematika di kelas VI SDN Karang Satria 04. Adapun langkah pembelajaran yang dilakukan adalah:

a) Pastikan siswa telah memasang aplikasi $X$-boX pada gawainya

b) Siswa memperhatikan penjelasan guru cara menggunakan aplikasi $X$-boX ini secara klasikal

c) Siswa dibagi menjadi 6 kelompok dan setiap kelompok terdiri dari 6 orang siswa, setiap kelompok diberi tugas kelompok untuk menyelesaikan perkalian dalam lembar kerja kelompok menggunakan aplikasi $X-b o X$ pada gawai.

d) Siswa membagi tugas untuk setiap anggota mengerjakan soal pada lembar kerja. 
e) Setiap kelompok membahas hasil perhitungan dan kelompok yang lain mengecek hasilnya menggunakan media $X-b o X$.

f) Siswa diberi lembar kerja siswa untuk mengerjakan soal perkalian yang ada menggunakan aplikasi $X$-boX secara perorangan.

Kendala yang ditemui dalam penggunaan Aplikasi $X-b o X$ pada pembelajaran diantaranya:

a) Tidak semua siswa memiliki gawai. Upaya yang dilakukan meminjamkan gawai milik guru.

b) Memerlukan waktu untuk mentransfer aplikasi dan memasangnya pada gawai siswa. Upaya yang dilakukan dengan melakukan transfer dan pemasangan aplikasi sebelum pelajaran dimulai.

Pada pembuatan dan penggunaan Media $X-b o X$ didapati beberapa kelebihan dan kekurangan. Kelebihan media $X-b o X$ diantaranya: Sesuai dengan pembelajaran abad 21 terkait literasi teknologi dalam menghadapi revolusi industri 4.0, satu-satunya media hitung berbasis android untuk Perkalian setelah kalkulator, media ini tidak 'mencederai' proses pembelajaran karena dalam penggunaan media ini siswa tetap melakukan proses berpikir, dapat menghitung perkalian sampai empat digit angka dengan tepat, siswa dapat mencoba berulang kali dengan angka yang berbeda sampai siswa paham betul caranya, pembelajaran menjadi lebih menarik dan menyenangkan, media pembelajaran dapat dijadikan sebagai media belajar offline dan gratis yang dapat digunakan setiap waktu tanpa menggunakan kuota data, menambah keterampilan guru dan siswa dalam penggunaan perangkat gawai, membantu siswa memahami perkalian dengan metode lain, dapat digunakan dan dioperasikan oleh semua guru dan siswa karena menggunakan perangkat gawai yang umum digunakan.

Kekurangan dari media ini antara lain: dalam pembuatan dibutuhkan waktu yang panjang agar hasil bisa maksimal, pembuatan rumus pada bahasa pemrograman memerlukan ketelitian agar hasilnya 


\section{Kristiningrum}

akurat. Data rata-rata hasil belajar siswa yang diperoleh dari penelitian yang telah dilakukan adalah :

Tabel 1 Rerata Hasil Belajar Siswa

Sebelum dan Sesudah Menggunakan X-boX

\begin{tabular}{|c|c|c|}
\hline Keterangan & $\begin{array}{c}\text { Sebelum } \\
\text { Menggunakan Media } \\
\boldsymbol{X} \text {-boX }\end{array}$ & $\begin{array}{c}\text { Sesudah Menggunakan } \\
\text { Media X-boX }\end{array}$ \\
\hline $\begin{array}{c}\text { Nilai Rata-rata } \\
\text { Kelas }\end{array}$ & 58 & 91 \\
\hline KKM & $28 \%$ & $100 \%$ \\
\hline
\end{tabular}

Sedangkan hasil validasi materi dan validasi media yang telah dilakukan oleh ahli adalah sebagai berikut.

Tabel 2 Hasil Validasi Ahli

\begin{tabular}{|c|c|c|c|c|}
\hline Validasi & Skor & Persentase & Rerata Skor & $\begin{array}{c}\text { Rentang } \\
\text { Skor }\end{array}$ \\
\hline Media & 58 & $82 \%$ & 4,3 & $>4,2$ \\
\hline Materi & 94 & $94 \%$ & 4,7 & $>4,2$ \\
\hline
\end{tabular}

\section{Analisis Hasil Aplikasi Praktis Inovasi Pembelajaran}

Penggunaan media $X$-boX ternyata dapat meningkatkan hasil belajar dan pemahaman siswa tentang perkalian. Ketika menggunakan cara bersusun hanya $28 \%$ dari 39 orang siswa mendapat nilai diatas KKM dan sisanya $72 \%$ dibawah KKM, dengan nilai rata-rata kelas yang di peroleh 58. Setelah menerapkan media $X$-boX siswa yang memperoleh nilai diatas KKM sebesar $100 \%$ dan tidak ada yang berada dibawah KKM dimana nilai rata-rata kelasnya 91 Data hasil nilai perolehan siswa pada perkalian menggunakan cara bersusun dan media $X-b o X$ tertuang pada grafik berikut. 


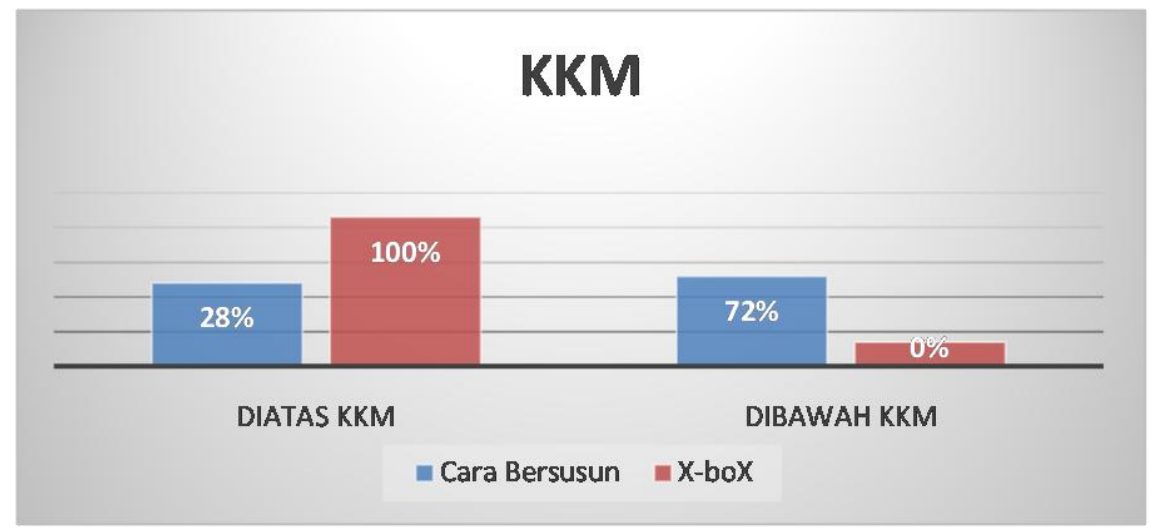

Grafik 1 Pencapaian KKM Dengan Menerapkan

Cara Bersusun dan media $X$ - $b o X$

\section{Nilai Rata-rata Kelas}

58

\section{1}

n Cara Bersusun $\mathbf{X}$-boX

Grafik 2 Rata-rata Kelas Dengan Menerapkan

Cara Bersusun dan Media X-boX

Pada grafik diatas dapat diketahui bahwa penerapan media $X$-boX ternyata dapat meningkatkan hasil belajar siswa dengan ditandai bertambahnya siswa yang mendapat nilai diatas KKM dan berkurangnya siswa yang memperoleh nilai dibawah KKM. Selain itu dari grafik terlihat nilai rata-rata kelas pun meningkat dengan signifikan.

Pembelajaran Matematika dengan media $X-b o X$ ini juga membuat siswa lebih bersemangat dan menyukai pelajaran matematika khususnya perkalian. Selain itu media $X-b o X$ ini pun merubah persepsi siswa, dimana awalnya siswa menganggap matematika pelajaran yang sulit menjadi pelajaran yang mudah. Hal ini dibuktikan dengan hasil angket siswa pada perbandingan cara bersusun dengan media $X-b o X$ yang dituangkan dalam grafik berikut. 


\section{Kristiningrum}

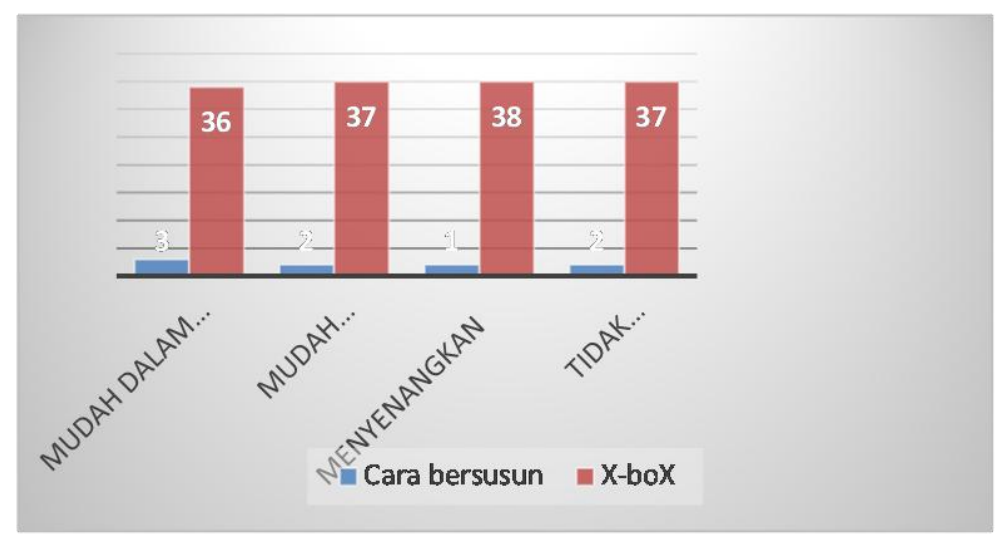

Grafik 3 Perbandingan Cara bersusun dengan Media X-boX

Dari grafik diatas dapat diketahui bahwa 91.89\% siswa merasa lebih mudah menggerjakan perkalian menggunakan media $X$-boX daripada cara besusun. Selain itu 94,5 \% siswa juga lebih mudah mengerti, merasa senang dan tidak merasa bosan ketika mengerjakan perkalian dengan media $X$-boX. Ini berarti media $X$-boX sangat baik untuk diterapkan pada pembelajaran tentang perkalian. Beberapa siswa menyampaikan alasan mereka lebih menyukai $X$-boX karena bisa lebih teliti, lebih berwarna dan menggunakan media berbasis android/ gawai memberi pengalaman baru yang cukup menyenangkan.

Karya inovasi pembelajaran $\mathrm{X}$-boX melalui proses validasi secara kualitatif dimana menggunakan analisa data berdasarkan mutu dengan satu variabel. Validasi ini menggunakan skala yang dikembangkan berikut ini.

Tabel 3 Pedoman Skor Penilaian

\begin{tabular}{|c|c|c|}
\hline $\begin{array}{c}\text { Data berdasarkan nilai } \\
\text { jumlah }\end{array}$ & $\begin{array}{c}\begin{array}{c}\text { Data Berdasarkan nilai } \\
\text { mutu }\end{array} \\
\end{array}$ & Rumus skor rata-rata: \\
\hline 1 & KS (Kurang Sekali) & \multirow{5}{*}{$\bar{X}=\frac{\text { Jumlah Skor }}{\text { jumlah kriteria penilaian }}$} \\
\hline 2 & K (Kurang) & \\
\hline 3 & C (Cukup) & \\
\hline 4 & B (Baik) & \\
\hline 5 & BS (Baik Sekali) & \\
\hline
\end{tabular}

Sumber : (Usman \& Setiady, 2011) 
Skor berdasarkan nilai jumlah atau nilai rerata total diubah menjadi nilai berdasarkan mutu (kualitatif). Perubahan skor tersebut menggunakan kualifikasi berikut.

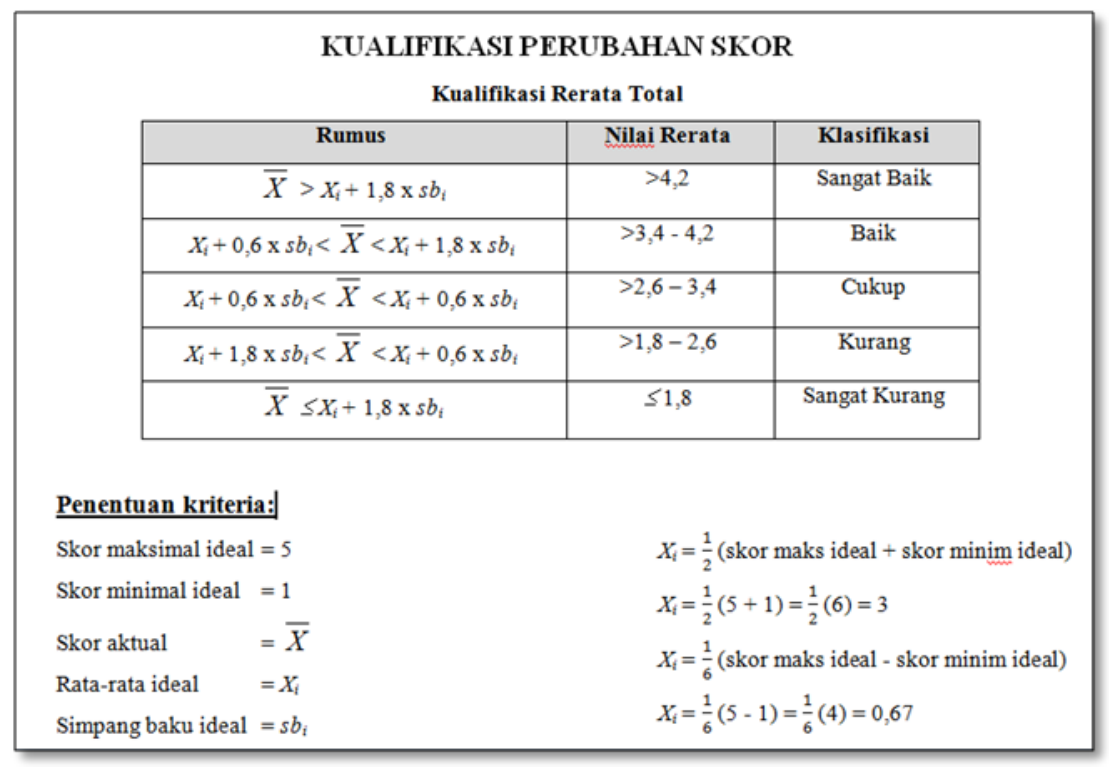

Sumber : (Widoyoko, 2009)

Dari data pada tabel 3.2 karya inovasi $X$-boX masuk dalam kategori Baik Sekali (BS) untuk hasil validasi dari ahli materi dan mendapat kategori yang sama yaitu Baik Sekali (BS) dari validari ahli media. Dari hasil tersebut karya inovasi pembelajaran $X-b o X$ dinyatakan layak digunakan sebagai media pembelajaran matematika.

\section{Penutup}

Berdasarkan hasil penelitian diketahui bahwa siswa mulai menyukai pelajaran matematika setelah materi perkalian disajikan dengan aplikasi pada smartphone berbasis android (media X-boX), sehingga siswa antusias dan menjadi lebih bersemangat belajar. Pemahaman siswa pada materi perkalian menjadi lebih baik. Lebih banyak siswa yang memperoleh hasil belajar diatas KKM. Nilai rata-rata kelas juga turut meningkat secara signifikan. Penerapan dan pengembangan media X-boX 


\section{Kristiningrum}

menurut para ahli materi dan ahli media menyatakan bahwa media ini layak untuk digunakan sebagai media pembelajaran.

\section{Ucapan Terimakasih}

Terima kasih kepada Subdit Kesharlindung pada Direktorat Pembinaan Guru Pendidikan Dasar - Direktorat Jendral Guru dan Tenaga Kependidikan Kementerian Pendidikan dan Kebudayaan, atas kesempatan yang telah diberikan kepada penulis dalam mengikuti kegiatan inovasi pembelajaran. Ucapan terima kasih disampaikan pula kepada Kepala Sekolah SDN Karang Satria O4 atas dukungan dalam kegiatan dan penelitian ini. Juga terima kasih kepada dewan guru dan staf di SDN Karang Satria 04 Kecamatan Tambun Utara, yang telah memberi semangat, motivasi, serta turut berpartisipasi dalam kegiatan diseminasi hasil penelitian ini. Kepada seluruh pihak yang telah banyak membantu, semoga menjadi amal sholeh yang pahala yang berlipat ganda dari Tuhan YME. Amiin.

\section{Daftar Referensi}

Briggs, L. J. (1981). Handbook of Procedures for The Design of Instruction, 2nd edition. Englewood Cliffs: Educational Technology.

Gagne, E. D. (2006). The Cognitive Psychology Of School Learning. Boston, Toronto: Little Brown and company.

KBBI. (2019, Maret). Retrieved from KBBI: http://kamusbahasaindonesia.org/pengembangan/mirip.

Keswara, R. (2016, Juni 21). sindonews.com. Retrieved September 22, 2017, from https://daerah.sindonews.com.

Nurjayanti, A. I. (2015). Pengembangan Media Pemebalajaran Matematika Berbasis Android Untuk Siswa Kelas 3 Sekolah Dasar. eprints@UNY.

Nurmasari, L. (2010). Retrieved September 15, 2017, from https://eprints.uns.ac.id/8112/1/20855151120110737. 
Setyadi, D. (2017). Pengembangan Mobile Learning Berbasis Android Sebagai Sarana Berlatih Mengerjakan Soal Matematika. staff.uksw.edu.

Siswanto, R., Sugiono, S., \& Prasojo, L. (2018). The Development of Management Model Program of Vocational School Teacher Partnership with Business World and Industry Word (DUDI). Jurnal Ilmiah Peuradeun, 6(3), 365-384. doi:10.26811/peuradeun.v6i3.322.

Steve, S. (2005). Matematika Praktis Untuk Sekolah Dasar Kelas I dan II. Bandung: Rekarya Jaya.

Sumarno, A. (2012). Perbedaan Penelitian dan Pengembangan.

Wiryokusumo, I. (2011). Dasar-dasar Pengembangan Kurikulum. Jakarta: Bumi Aksara. 